\section{J O U R A L O F}

French and Francophone Philosophy
REVUE DE LA

philosophie française et de langue française

\title{
Human Rights and the Leap of Love
}

\author{
Alexandre Lefebore
}

Journal of French and Francophone Philosophy - Revue de la philosophie française et de langue française, Vol XXIV, No 2 (2016) 21-40.

\author{
Vol XXIV, No 2 (2016) \\ ISSN 1936-6280 (print) \\ ISSN 2155-1162 (online) \\ DOI $10.5195 /$ jffp. 2016.769 \\ www.jffp.org
}

\section{(c) EY-NC-No}

This work is licensed under a Creative Commons Attribution-Noncommercial-No Derivative Works 3.0 United States License.

\section{ULIS D-Sunte}

This journal is operated by the University Library System of the University of Pittsburgh as part of its D-Scribe Digital Publishing Program, and is co-sponsored by the University of Pittsburgh Press 


\section{Human Rights and the Leap of Love}

\section{Alexandre Lefebvre}

University of Sydney

For years in Anglophone scholarship on Henri Bergson it has been a convention to remark that one was writing on a once famous but now forgotten philosopher. Thankfully, on the $75^{\text {th }}$ anniversary of his death, it is safe to say this is no longer the case. His major French interlocutors are either widely translated into English (such as Gilles Deleuze) or else are in the process of being so (such as Vladimir Jankélévitch and Frédéric Worms). And today there are outstanding books in English on nearly every branch of his thought from his philosophy of time, to psychology, metaphysics, evolutionary theory, aesthetics, practical philosophy, theology, and his impact on subsequent philosophy. ${ }^{1}$

This said, if there is one area of his oeuvre to which this convention might still apply to it is his social and political philosophy, and in particular, to his last book, The Two Sources of Morality and Religion (1932). There are, to be sure, valuable works that trace the impact of his thought on later political thinkers and figures, or else that situate Bergson's work within wider discourses of power, politics, and empire. ${ }^{2}$ But this is different from developing his political philosophy on its own terms and assessing what resources it has to offer us here and now. In my previous book I tried to develop Bergson's political philosophy with a focus on human rights. ${ }^{3}$ In this article I take up the same topic but with a different aim and from a different angle. First, I want to give Bergson's message on human rights in a short, clear form that is accessible to those readers who are unfamiliar with him. I believe there is something very simple and powerful in Bergson's conception of human rights that can contribute to a wider community of scholarship and activism. Second, I will stress a surprising and useful facet of his approach to human rights, namely that human rights are a tool to help individuals transform and cultivate themselves. To put the point directly, Bergson sees human rights as the best resource available to us in our present day and age to infuse our lives with a loving and joyful sensibility. Thus, human rights are not simply an institution and discourse that advances global social justice, but Bergson also shows how human rights are a means 
for individuals to care for themselves. This is the simple message I hope to convey in this article.

\section{Henri Bergson}

To introduce Bergson to a wider audience it is best to begin with a bit of biography. Bergson, it may be surprising to learn, is significant to the human rights project not merely for his intellectual contribution but also because he was an important actor in early twentieth century internationalism.

Our story begins in 1916 when the French government entrusted him with a series of diplomatic assignments, first to Spain and then, much more importantly, to the United States. The purpose of this second assignment was to strike up a personal relationship with President Woodrow Wilson in order to persuade the United States to enter the Great War. Now, on first impression, Bergson would seem to be an unlikely candidate for such a momentous task. At the time he was the world's most renowned philosopher, and he spoke impeccable English, but he had next to no experience in diplomacy or political affairs. And yet his nomination was astute. For what Bergson was able to do, precisely because he was an eminent philosopher, was to reflect the President's own sense of historic mission back to him. Bergson's biographers put it nicely: "In essence, Bergson says to Wilson: 'you are philosopher, prophet, and king. For the first time in human history these three figures are one.' And if Bergson is persuasive, it is because he believes what he says. In this sense, Bergson is truly 'witness to the truth': he presents Wilson the very image he would like to have of himself. He is witness to Wilson's desire; or in other words, he guarantees Wilson's ideal self. Only a philosopher could have provided this guarantee." 4

Bergson is thus at the heart of a world historic event: the entry of the United States into the First World War. But his foray into politics and diplomacy didn't end there. Due to his close relationship with the Wilson Administration, his role in the Paris Peace Conference as a negotiator between France and the United States, and his own intellectual stature, Bergson was appointed President of the League of Nation's newly founded Commission for Intellectual Cooperation. Forerunner to UNESCO, the goals of the Commission may seem modest. It was created to foster intellectual cooperation between member nations, including student and scholar exchanges, translation of scholarship, dissemination of scientific results, and reports on intellectual life in member countries. By all accounts, Bergson took his responsibilities very seriously. A touching story has him pouring over his notes, "like a schoolboy before an exam," prior to a meeting to request a small sum from the League. ${ }^{5}$ Yet all this hard work was done with a real sense of purpose. In his mind, the Commission was nothing less than the spiritual wing of the League of Nations and indispensable to its broader 
aim of internationalism. As he states in his Presidential address, "In asking us to lay the foundation of an organization for international cooperation the League of Nation has set a mainly scientific goal. But at the same time it probably also pursues a moral goal, the very one it has set for itself: to raise a great monument to fraternity, to solidarity and accord between people." 6 Thus, in these two posts-as emissary to the United States during the Great War and as president of the Commission for International CooperationBergson is both a philosopher who influenced the highest levels of policy and also an administrator who labored for a philosophical ideal. He is, to borrow a phrase from Mary Ann Glendon, one of those rare figures to have straddled the forum and the tower. ${ }^{7}$

The circumstances of his last days and death are poignant for a human rights imagination. ${ }^{8}$ By 1941 the Nazi occupation of France had begun and the first discriminatory laws introduced. According to several testimonies, the Pétain government had offered Bergson the title of "honorary Aryan," as the Jewish descent of France's greatest living philosopher posed some embarrassment. Bergson not only declined the title but also made a great effort, crippled as he was by arthritis and helped along by nurses, to line up on a cold winter's day and register himself as a Jew - the cruel irony being that he probably contracted the bronchitis that killed him on this occasion. Last, although these letters have been lost, just before he died Bergson is reported to have renounced in writing all honors and titles bestowed on him by France, distinctions which he cherished. A sad end for a man who championed international cooperation in politics and who was often reproached for optimism in his philosophy.

\section{A Contemporary Human Rights Debate}

Bergson's reflections on human rights are found almost entirely in his last book, The Two Sources of Morality and Religion. It was published in 1932, a year that falls between his hopeful work on internationalism and the tragedies of the late 1930s and early 1940s. Now, it wouldn't be accurate to suggest that Bergson has a fleshed out theory of human rights in Two Sources. His discussion is confined to roughly a dozen pages scattered throughout the book. What he offers, instead, are flashes of insight in his remarks on human rights, remarks which are embedded within a broader reflection on morality, religion, and politics.

Rather than plunge directly into Two Sources, I would like to introduce Bergson's relevance for a contemporary audience by way of a present-day debate. In recent years no work has generated more interest or controversy in the field of human rights as Samuel Moyn's Last Utopia (2010). Moyn's thesis is that the human rights project as we know and practice it today is of relatively recent vintage, indeed much more so than we typically imagine. Far from coming out of the great political revolutions of the late eighteenth 
century, Moyn claims that human rights emerged as a viable and popular moral, legal, and political phenomenon only in response to the collapse of socialist and liberal utopias in the mid-to-late 1970s. The reason why it flourished at this time is because it offered a minimalist and moral alternative to failed political paradigms. ${ }^{9}$ "In this atmosphere," Moyn explains, "an internationalism revolving around individual rights surged, and it did so because it was defined as a pure alternative in an age of ideological betrayal and political collapse."10

As one can imagine, this thesis has been debated in different disciplines. For political theorists it raises issues as to whether socialist and liberal utopias are truly dead, whether the concept of utopia in general remains productive, and whether human rights help to remake our political sensibility and to what end. ${ }^{11}$ But the main controversy The Last Utopia has stirred up is in the discipline of history, for the good reason that its critical thrust is directed at the historiography of human rights and what Moyn attacks as its progressivism and triumphalism. Here is his indictment:

Historians in the United States started writing the history of human rights a decade ago. Since that time, a new field has crystallized and burgeoned. Almost unanimously, contemporary historians have adopted a celebratory attitude toward the emergence and progress of human rights, providing recent enthusiasms with uplifting backstories and differing primarily about whether to locate the true breakthrough with the Greeks or the Jews, medieval Christian or early modern philosophers, democratic revolutionaries or abolitionist heroes, American internationalists, or antiracist visionaries. [...] They have used history to confirm their [i.e., human rights] inevitable rise rather than register the choices that were made and the accidents that happen. ${ }^{12}$

On Moyn's account, nearly all historians of human rights have fallen into the same trap: teleology. Indeed, all that really distinguishes them is the date from which they begin to narrate the steady march to our human rights present: whether it be ancient, Christian, early modern, and so forth. But perhaps his main target-or at least, a highly representative one-is Lynn Hunt's Inventing Human Rights (2008).

Hunt is a leading American historian and in Inventing Human Rights she locates the origins of human rights in a widespread cultural transformation that takes place in the eighteenth century. She starts from the premise that human rights require a society at large (or at least its middle and upper classes) to undergo a sentimental education in order to become widely accepted. Her basic claim is that human rights are to become popular as an ideal and institution, it is necessary for people to learn to empathize more broadly beyond their own narrow group. They must be able, in a word, to step into the shoes of a wide variety of others. "Human 
rights are not just a doctrine formulated in documents," Hunt states. "They rest on a disposition toward other people, a set of convictions about what people are like and how they know right and wrong in the secular world. Philosophical ideas, legal traditions, and revolutionary politics had to have this kind of inner emotional reference point for human rights to be truly 'self-evident' [...] and these feelings had to be felt by many people, not just the philosophers who wrote about them." 13

Much of Hunt's book is spent documenting the ways in which sentimental education occurs in the eighteenth century. For example, she turns to the immense popularity of epistolary novels - such as Richardson's Pamela (1740) and Clarissa (1747-1748), and Rousseau's Julie (1761) - to argue that this genre prepares a reading public to empathize across more broadly defined boundaries. ${ }^{14}$ The reason why this kind of sentimental education is so crucial to her argument is that it matches and sustains what she calls the "inner logic" of human rights. ${ }^{15}$

This logic is as follows. Universal rights are declared at a particular point in time (her book focuses on the French Declaration of the Rights of Man and Citizen of 1789). Afterwards comes the messy business of deciding to whom and what these rights actually apply. Hunt marshals a wealth of documentary evidence to depict the extension of universal rights as a series of ever widening inclusions. In France, the first groups to be extended rights were perceived as more or less unobjectionable, such as Protestant males. Then, following in their wake, more marginal groups petitioned for these same rights on the basis of the previous extension. It is from this process that Hunt infers the "inner logic" of human rights:

The French revolution, more than any other event, revealed that human rights have an inner logic. As the deputies faced the need to turn their lofty ideals into specific laws, they inadvertently developed a kind of conceivability or thinkability scale. No one knew in advance which groups were going to come up for discussion, when they would come up, or what the resolution of their status would be. But sooner or later, it became clear that granting rights to some groups (Protestants, for example) was more easily imagined than granting them to others (women). The logic of the process determined that as soon as a highly conceivable group came up for discussion (propertied males, Protestants), those in the same kind of category but located lower on the conceivability scale (propertyless males, Jews) would inevitably appear on the horizon. ${ }^{16}$

Hunt is fond of calling this process a "cascade."17 But we could also think of it as a series of concentric circles. Rights and sympathy are at first gathered into a small and exclusive core (say, propertied Christian males). Yet, over time, the effects start to ripple outward, growing wider and wider, until 
eventually such rights and sympathy reach the outer shore of humanity as a whole. Such a process may take years, decades, even centuries. But, according to Hunt, the Enlightenment unleashes an inexorable force of sympathy and fellow human feeling that over time will vanquish prejudice and establish an international human rights culture and regime. To quote the title of her penultimate chapter, which she herself takes from John Adams, "There will be no end to it."18

Now this is exactly the kind of history of human rights that Moyn takes to task in Last Utopia. It is entirely too progressivist, too laminar, and too triumphalist to be creditable. It presupposes that the institutions, sentiments, rivals and opponents of human rights remain steady over centuries, whether in their first iteration as the rights of man in 1789, or in their relative disappearance in the nineteenth century of state-building and colonialism, or in their adoption by the League of Nations and the United Nations for state-centric internationalism, or right up until our own contemporary global movement that champions human rights as checks and limits on states. This kind of narrative is not properly historical for Moyn. It is, in his words, "church history." 19

It is at this point that I would like to reintroduce Bergson. He too would strongly object to Hunt's teleology and progressivism, but for different reasons. His quarrel would not be with her depiction of history. Rather, it would be with her account of sentiment, and in particular, with her account of the nature and spread of sympathy. Hunt thinks that sympathy for other people (which for her underlies human rights) can radiate out indefinitely. Properly cultivated it can expand from family, to tribe, to nation, all the way to humanity. But for Bergson this ignores something essential: morality is not infinitely extendable. It has limits, biologically built-in limits, and to turn a blind eye to these is catastrophic for the theory and practice of human rights. I explain why in the following section.

\section{The Critique of Human Rights}

A key respect in which Bergson remains our contemporary, even seventyfive years after his death, is that he is a naturalist moral philosopher. Whereas many peers of his time thought that human beings were inherently selfish and vicious, he held that we are naturally sociable, cooperative, and other-regarding. His reason is simple: there are tremendous evolutionary advantages to solidarity and cooperation. Thus, rather than see human beings as naturally bad, as "red in tooth and claw," he suggests that we are naturally good. Morality - and all that goes with it, including empathy, cooperation, reciprocity, and solidarity - is not extrinsic to our evolved nature. It is a product of it. 
The first thirty pages of Two Sources develop this point. But it is at this early stage of his book that Bergson makes a crucial move. If, as he says, morality "is in essence biological," i.e., if we instinctively care and feel for our fellows, it follows that morality has sharp natural limits. ${ }^{20} \mathrm{He}$ does not mince words: "Who can help seeing that social cohesion is largely due to the necessity of a community to protect itself against others, and that it is primarily as against all other men that we love the men with whom we live? Such is the primitive instinct." 21 This, then, is the critical point: if the biological function of morality is to ensure the cohesion and solidarity of groups (and thus to help ensure the survival of the individual), it means that the scope of moral obligation extends no further than the group, however large it may be. To use Bergson's term, to a greater or lesser degree, all societies are constitutively "closed." Underpinned by our natural morality, "their essential characteristic is [to] include at any moment a certain number of individuals and exclude others." 22

This view closely anticipates present-day naturalist accounts of morality. Consider, for example, the eminent primatologist Frans de Waal. In his 2004 Tanner Lectures on Human Values at Princeton University he also argues that morality is the outgrowth of our evolved cooperative tendencies. ${ }^{23}$ Just as Bergson does, he observes that this entails an underside. "It should be noted," says de Waal, "that the evolutionary pressures responsible for our moral tendencies may not have all be nice and positive. After all, morality is very much an in-group phenomenon." 24 And in a later lecture he continues, "Morality evolved to deal with [one's] own community first, and has only recently begun to include members of other groups, humanity in general, and non-human animals. While applauding the expansion of the circle, this expansion is constrained by affordability, that is, circles are allowed to expand in times of abundance but will inevitably shrink when resources dwindle. [...] A level playing field, in which all circles count equally, clashes with ancient survival strategies." 25 According to de Waal, then, only in times of abundance are groups able to expand moral concern and consideration to distant others. When times are tough and resources scarce, the circle of morality contracts to a core membership.

On these two issues Bergson and contemporary naturalism are fully consistent: first, that morality is a product of evolution; and second, that as a consequence it has limits as to how far it can extend. This is where we return to Hunt and Inventing Human Rights. Moyn's criticism, recall, is that the historical progress of human rights she describes is all too smooth and constant. Bergson would have a similar objection, though with a different target: that the expansion of sympathy she describes is all too smooth and constant. Hunt believes that sympathy has the capacity to grow until it encompasses all of humanity. All it has to do is overcome prejudice. Yet for Bergson this ignores the very real limit of evolved morality. Sympathy 
cannot fully shed its origin: it was made for groups and to groups it shall remain.

This is of basic importance to Bergson's theory of human rights. As we will see, he too believes that such rights can be universal and encompass all of humanity. But he is deeply skeptical that such universality can be achieved by extending sympathy and moral obligation from smaller to bigger groups. Indeed, to think otherwise is not just mistaken but mendacious. That is the message of a key critical passage in Two Sources:

When we lay down that the duty of respecting the life and property of others is a fundamental demand of social life, what society are we talking about? To answer we need only consider what happens in time of war. Murder and pillage, as well as perfidy, fraud and lies become not only lawful; they are praiseworthy. Just like the witches of Macbeth, the belligerents will say: "Fair is foul, and foul is fair." Would this be possible, would the transformation take place so easily, generally and instantaneously, if it were really a certain attitude of man toward man [i.e., of human beings toward human beings] that society had recommended up till then? Oh, I know what society says (it has, I repeat, its reasons for saying so); but to know what it thinks and what it wants, we must not listen too much to what it says, we must look at what it does. It says that the duties it defines are indeed, in principle, duties toward humanity, but that under exceptional circumstances, regrettably unavoidable, they are for the time being suspended in practice [l'exercice s'en trouve suspendu]. ${ }^{26}$

Bergson is not an author prone to sarcasm. Here, however, his temper seems pushed to its limit. Yet we should be clear about what draws his ire. Bergson is not upset that in times of war morality flips its general orientation, such that what was once foul now becomes fair (and vice versa). That's just the nature of morality. Sympathy and obligation are born from evolution and it would be misguided to expect them to lead beyond the mutual preservation of self and society. What infuriates him is the moralism and hypocrisy of pretending to ground human rights on sympathy and moral obligation. In refusing to acknowledge the inherent closure of morality, moral and political promises are issued that will not be kept in moments of crisis.

This criticism can be put more starkly. Bergson's argument is not just that sympathy and obligation are an inappropriate foundation for human rights. That much is obvious. The real issue is that the purpose of human rights is to defend people from sympathy and obligation, that is to say, from sympathy and obligation when they (inevitably) contract back into a narrow group. This is why a theory of human rights such as Hunt's is misguided. Its progressive narrative misdescribes the social, psychological, and affective basis of human rights. Worse, by configuring human rights as an extension 
of our closed moral nature-of our sympathy and obligation-she links human rights to the very thing they are meant to guard against.

We can bring this criticism home by placing Two Sources in its context. Written in dark times. Bergson has the ravages of the Great War just behind him, and the explicit anticipation of the Atomic Age just in front. ${ }^{27}$ It is not for nothing that in a later interview he remarks, "Hitler proved the truth of the two sources." $28 \mathrm{He}$ is acutely aware that sympathy and obligation are potentially very dangerous. It is by confining duty and sympathy to an exclusive group, to "people like us," that one group of people persecute and attack another. Thus, to return to our problem, we can see why for Bergson it is a terrible mistake to presume that human rights are based on the kind of sympathy and obligation that holds groups together. It makes what should be a shield against closed morality a pillar for it.

\section{The Closed Life}

In my previous book on Bergson I discussed at length this failure of human rights - or rather, this failure of human rights as modeled on the extension of sympathy and obligation - to protect all human beings. ${ }^{29}$ In this article, however, I would like to focus on a second danger that Bergson identifies. It is that closed morality, if unchecked, threatens to enclose human beings - all human beings, insiders and outsiders alike-in a stunted emotional and spiritual life.

Let me explain. Closed morality has an unattractive name-who likes to be called "closed," after all? But the truth is that the meaning of this term is more nuanced than meets the eye. Throughout Two Sources Bergson identifies its many healthy emotions and virtues. In the early part of the book he lists the best and most prominent which include discipline and selfsacrifice, obedience, solidarity and fellowship, honesty and fairness, tranquility, loyalty, security, and patriotism. ${ }^{30}$ That said, although a life guided by closed morality may not be awful or even unhappy, it is nevertheless limited. It crowds out a whole range-a whole half, in Bergson's words - of joyful affects and passions. In particular, it closes off emotions and experiences that depend either on dissolving and dissipating the self (such as joy and heroism) or else on leaping beyond a closed community (such as love and charity). And the reason it does so, i.e., the reason why certain emotions and experiences are inaccessible to closed morality, is because it is constitutively self-centered. This is the paradox of closed morality: it turns self and society toward one another in a mutually reinforcing and mutually regarding relation of sympathy and obligation. The individual, he states, "is part and parcel of society; he and it are absorbed together in the same task of individual and social-preservation. Both are self-centered." 31 And again: "At once individual and social, the soul here moves round in a circle. It is closed." 32 
In and of itself there is nothing wrong with this self-centered nature. Closed morality is a product of evolution and we should not expect it to behave otherwise. Yet what would be dispiriting is to assume that closed morality exhausts all possible permutations of morality, i.e., that closed morality is the foundation of not just of exclusive attachments (such as to family or country), but of open and universal ones as well. For what is lost in this assumption-or better, what we lose of ourselves in this assumption-are, in the words of Jankélévitch, "[all] those absurd and useless virtues without which life would lose all its value." 33

Here, then, is the second criticism Bergson makes of human rights as an extension of sympathy and obligation: We become personally and spiritually trapped in closed morality. Or, to speak more precisely, by basing human rights in closed morality we transform one of the most powerful tools (i.e., human rights) to help us escape from the psychic life of closed morality into just another support for it.

As we will see in the next section, for Bergson the best and most important thing human rights can do is to initiate all human beings into emotions that closed morality knows nothing about: truly open love, and joy. It is precisely that potential which is ruined by seeing human rights as nothing but expanded sympathy and obligation. Consider here Jankélévitch's depiction of the great gradualist dream of (closed) morality: "In ethics, such a symmetry [between closed and open morality] would not only be economical, it would also be reassuring; to enlarge domestic and corporative solidarity in small doses and to obtain, at the end of this magnificent widening, charity: what a godsend for egoism! Virtue and group interest would finally be reconciled. [...] Charity will appear as the superlative of egoism!"34 Jankélévitch's tone (and Bergson's too, as I noted above) is contemptuous: he leads us to picture a self-satisfied soul, greedy in spirit and flabby in mind, who wants to have his ethical cake and eat it too. But just as contempt lurks in pity, so too is there pity in contempt. For Bergson (as well as for Jankélévitch) such a person is an object of concern as well as one of criticism. The way in which he tries to clutch at charity - as if openness meant only to broaden the closed-all but ensures that an open love and joy elude him.

\section{Human Rights as Works of Love}

One way to think of Two Sources is as a book on love. Or rather, as a book on two different kinds of love. There is the kind of "closed" love I've described: an intensely felt attachment for a specific person or group. But there is also "open" love: an equally intensely felt attachment but that is non-exclusive and universal. What Bergson means exactly by open love is difficult to explain. The closest available concept is Christian agape. For the moment, 
however, let us say that open love refers less to a particular relation to an object or beloved and more to an exalted state or attitude of the soul.

Now, for Bergson, love-closed or open-is not just a feeling or an inner state of mind. It is a veritable creative force. It is capable of crystallizing into a doctrine, a work of art, an institution, and many other forms. ${ }^{35}$ For example, as I write, presidential candidates in the United States are proposing to build a wall along the border with Mexico. That wall would be a crystallization - a brutal and literal concretization - of closed love. But open love can crystallize as well. In Two Sources Bergson points to several occasions in history where individuals, moved by such love, create lasting works from it. These include, "the sages of Greece, the prophets of Israel, the Arahants of Buddhism, and others besides." 36 His two privileged examples, however, are Christianity and the Sermon on the Mount, and human rights and the Declaration of the Rights of Man and Citizen. These are the paradigmatic moments in which humankind has sought to overcome the boundaries of the closed society. Bergson writes,

The morality of the Gospels is essentially that of the open soul: are we not justified in pointing out that it borders upon paradox, and even upon contradiction in its more specific recommendations? If riches are an evil, should we not be injuring the poor in giving them what we possess? [...] But the paradox falls away, the contradiction vanishes, if we consider the intention of these maxims, which is to induce a disposition of the soul [un état d'âme]. It is not for the poor, but for his own sake, that the rich man should give up his riches. [...] We should need then, strictly speaking, a direct expression of the movement and the tendency; but if we still want-and we cannot avoid it-to translate [them] into the language of the static and the motionless, we shall have formulas that border on contradiction. ${ }^{37}$

Of all political systems, [democracy] is indeed the furthest removed from nature, the only one to transcend, at least in intention, the conditions of the "closed society." It confers on man inviolable rights... [Democratic theory] proclaims liberty, demands equality, and reconciles these two hostile sisters by reminding them that they are sisters, by exalting above everything fraternity. Looked at from this angle, the republican motto shows that the third term dispels the oft-noted contradiction between the two others, and that the essential thing is fraternity: a fact which would make it possible to say that democracy is evangelical in essence and that its motive power is love. ${ }^{38}$

I juxtapose these passages to make two points about the role of love in human rights. First, as I have said, human rights have their origin in love. To borrow a phrase from Kierkegaard, they are "works of love." And clearly, 
Bergson does not think that open love reveals itself only once in the history of human rights - as if the French Revolution and its Declaration was the sole occasion that it broke through. Closest to his heart is the League of Nations, the roots of which he traces to love and not tactical or pragmatic motivations. Indeed, it is because he thinks the League of Nations originates in open love that he so bitterly laments its failure: "Thus was lost the sole chance offered to the world, ever since the announcement of the Gospels, to infuse the evangelical spirit into relations between nations. Humanity would have raised itself to undreamed of heights. Instead it fell lower than ever. Corruptio optimi pessima [the corruption of the best is the worst of all]."39

The second point is that human rights have the power to spread love. As he says with respect to the Gospels, the intention of these maxims is to "induce a disposition of the soul." 40 In bringing love into the world, then, the Sermon on the Mount and the Declaration of the Rights of Man have the potential to introduce all human beings to a way of life that is open. That is their great purpose. Even if most of us are unable (or initially, unwilling) to create great works of love on our own, contact with such works has the potential to awaken this capacity within us. As Bergson says, "When we bring these great moral leaders [grands hommes de bien] to life in our minds, when we hear them speak and watch them act, we feel that they communicate to us something of their fervor, and that they sweep us up in their movement." 41 Such events and documents "echo" in all human beings and help stir, if only fleetingly, a kind of love distinct from preference and closure. ${ }^{42}$ That is why, for Bergson, the promise of the Sermon on the Mount and the Declaration of the Rights of Man, along with all other creations of love, is to turn each and every human being away from a life in which partiality and exclusion reign. In this respect, then, it is necessary to insert an addendum to a remark by Jankélévitch. 'This opening and mobilization of the soul has taken place" he states, "thanks to the Prophets first, then with Christianity." 43 For Bergson, this task is today continued by human rights.

\section{Love and Joy}

It is fine and well to say that human rights are created by open love. But what does that mean? What is this exalted spiritual condition to which human rights are meant to introduce all of us? Bergson never positively defines it. Instead, he offers an uncompromising contrast between open love and the kind of preferential and exclusive love characteristic of closed morality.

The other attitude is that of the open soul. What, in that case, is allowed in? Suppose we say that it embraces all of humanity, we would not be going too far, we would not even be going far enough, since its love may extend to animals, to plants, to all nature. And yet no one of these things which would thus fill it 
would suffice to define the attitude taken by the soul, for it could, strictly speaking, do without all of them. Its form is not dependent on its content. We have just filled it; we could just as easily empty it again. "Charity" would persist in him who possesses "charity," though there be no other living creature on earth. ${ }^{44}$

This is an astonishing comment on love. Bergson takes an emotion that, on first impression, seems to be warm and fuzzy and safe, and demonstrates how austere and almost unthinkable it becomes when pushed to its genuine meaning (which, for him, is really its only meaning). For in trying to imagine a truly universal and inclusive kind of love Bergson effectively asks us to conceive of it outside the categories of preference and esteem. And that is deeply counter-intuitive. Love is something we ordinarily take to be deserved, gain, and earned. We love something because it is worthy of it. Granted, love based on esteem has nice versions (such as friendship and marriage) as well as nasty ones (such as chauvinism). Still, the fact remains that all such kinds of love are inextricably bound up with preference, hence with closure and exclusion.

Open love rubs against all those concepts, practices, and forms of life by which we have come to learn what love is. Perhaps it is better to think of it not as love for something but as being in love, if we take the preposition to mean the state of being enclosed, engulfed, or surrounded by something. In this respect, open love is better expressed as a mood or disposition. It is a way of being in the world rather than an attachment to any specific thing in it.

Open love is the emotion from which human rights are born, and which they in turn disseminate. It unsettles and breaks through our ordinary way of being in the world, with its familiar orderings of preference and exclusion. But why, to ask a blunt question, is open love so good and desirable? Its appeal at a social and political level is obvious. Love is a bulwark - the bulwark - against closed morality. But on a micro-scale, i.e., at an ethical and existential level, why should people want to experience it firsthand?

There are two good reasons. First, open love is pure: it is unalloyed with preference, exclusion, or hatred. And that, Bergson makes clear, is something only rarely felt and enjoyed. "Who can help seeing," he asks, "that social cohesion is largely due to the necessity of a community to protect itself against others, and that it is primarily as against all other men that we love the men with whom we live? Such is the primitive instinct." 45 Here, then, is the first benefit of open love for individuals: in a very literal sense, it suspends the emotional life of our species. It holds out a momentary reprieve, necessarily fleeting and fragile, from a psyche naturally tainted by closure. ${ }^{6}$ Or, positively speaking, it makes available a whole gamut of 
emotions that closed morality blocks off access to, such as charity, simplicity, generosity, and joy. 47

The second reason why open love is desirable is closely related. It provides an escape from ourselves. Here one of the oldest known definitions of love is relevant. In Symposium, Plato claims that love means that I am not centered in myself. ${ }^{48}$ What Bergson does in Two Sources is push this idea to its limit. Closed morality, recall, along with its version of love, is constitutively self-centered. "At once individual and social the soul here moves round in a circle. It is closed." 49 According to Bergson, it is because open love splits this circuit, because it ruptures the mutual reinforcement of self and society, that it alone deserves the name love: it transcends the limit of a closed community and, just as crucially, leads the self beyond its social ego. Open love is what biologists might call a saltation, and it is no coincidence that Bergson uses the language of leaping and jumping - "un saut brusque" 50 - to describe the kind of movement and effort needed to break from the social self. 51

Now, from one perspective, the prospect of setting aside the social self is terrifying. As Bergson is the first to admit, closed morality is what gives our ego its sense of identity and purpose. "Its solidity lies in this solidarity." 52 Yet at the same time, he is clear that a great reward attends the leap. It leads to the best and highest emotion to which human beings can aspire: joy.

Joy is an important-and extraordinarily recurrent ${ }^{53}$-topic in Bergson's work. It is also an emotion that he always ties to a single feature or capacity of human nature: creativity and self-creation. He states this connection in several jubilant passages. For example, "Wherever there is joy, there is creation; the richer the creation, the deeper the joy." 54 Or again, "Philosophy stands to gain in finding some absolute in the moving world of phenomena. But we shall gain also in our feeling greater joy and strength. Greater joy because the reality invented before our eyes will give each one of us, unceasingly, certain of the satisfactions which are now and again procures for the privileged." 55 Or yet again, "The soul that is opening, and before whose eyes material objects vanish, is lost in sheer joy. Pleasure and well-being are something, joy is more." 56

Love and joy are intimately connected. But we must be precise about the connection Bergson establishes, for it is not the one that commonsense leads us to believe. Metaphorically speaking, but only metaphorically speaking, open love is "joyful" in that it is free of partiality, indifference, enmity, and exclusion. It is free, in Bergson's words, from the "morality of the city." 57 But love is not joy in and of itself. Neither does love elicit joy by filling our lives with more positive and less hateful affects. Joy is always and only tied to creation. Properly speaking, open love is joyful for Bergson not because it is not hateful but because it generates the deepest and most 
comprehensive kind of personal transformation. Closed morality may contain pleasure and comfort, but love and joy remain-conceptually, yet not experientially - separate. Love elicits joy through the creation of a new moral nature. ${ }^{58}$

This relation between love and joy matters for human rights. It is the second key respect in which human rights ameliorate our emotional or spiritual life. By introducing individuals to love, and thus potentially setting a deep personal transformation into motion, human rights elicit joy. By loosening the hold that the "morality of the city" has over us - or, more literally and strikingly, by loosening the hold that our evolved (closed) morality has over us-human rights deliver us to the joy of creation and self-creation.

\section{Human Rights, Love, and Other People}

In this article I have set Bergson against an orthodoxy in human rights discourse: that care and concern for the whole of humanity is reached by learning to broaden a narrower set of attachments. Lynn Hunt was my representative of this view, but in truth, it is widespread in modern and contemporary political thought. 59 To conclude, I would like to restate this contrast from another perspective. It goes to show just how radical and unfamiliar Bergson's approach to human rights is.

As I said, both Hunt (and many others) and Bergson agree that human rights require, and also foster, sympathy and generosity for humanity as a whole. The difference is how they get there. For Hunt, the process is step-bystep. Over time, and thanks to a process of sentimental education that begins in the Enlightenment, the ambit of sympathy and moral concern has been able to extend past kith and kin, include ever larger groups, and gradually encompass distant strangers and humanity as a whole. This, you may recall, is what she called the "inner" or "cascading" logic of human rights. 60

We know that for Bergson this is doomed to fail. Sympathy cannot indefinitely radiate outward because it was designed to-or rather, because it has evolved in order to-make groups internally cohesive. "The closed society," he says, "is that whose members hold together, caring nothing for the rest of humanity." 61 What then does he propose? How can human beings, saddled as we are with evolved morality, love universally?

Bergson's answer is complex and I cannot hope to fully address it here. ${ }^{62}$ The condensed version is that he adopts and reworks the Christian conception of agape. At the heart of Christianity is the idea that God creates a new relationship with humanity by loving us, in a way that we cannot love each other unaided. ${ }^{63}$ In Two Sources, Bergson preserves this scheme, but he makes a crucial substitution and addition. Instead of God enabling love, it is what Bergson calls "life," "evolution," or the "élan vital" that performs this 
role. "Love" is the name he gives to the emotion (sentiment, in French) that accompanies our power to tap into and realize the essence of life itself: interconnection, mobility, creativity, and movement. "By going deeply into this new aspect of morality," says Bergson in reference to love, "we should find the feeling of a coincidence, real or imaginary, with the generative effort of life." 64 And more succinctly: "[Love's] direction is exactly that of life's élan." 65

Here is the point I wish to make: Open love is exactly the kind of love that Bergson thinks human rights teach, but it is not in the first instance a love we feel for other people. It is not inspired by other people. It is not even exactly directed to other people. Love, instead, is Bergson's word for the exaltation and intensity of being that comes through immersion in life (what, in Christianity, was understood as immersion in God).

With this, Bergson turns our normal way about thinking about love for humanity, as well as humanitarian concern, on its head. Why? Because love for other people-along with the kind of sympathy, attention, solicitude, and care for other people that Hunt describes - is, according to him, a by-product of an altogether different and higher kind of love; one that is essentially unconcerned with any particular object, including other people. That is not to say that Bergson downplays love for distant strangers or love for humanity. But, unlike closed and exclusive love, an open and universal love cannot be attained by direct attachment to its object. We learn to love all others on condition that we do not set out to love specific others. Or, as Bergson says, "[Love] has not aimed at an object; it has shot beyond and reached humanity only by passing through it." 66

Louis Lavelle, an existential philosopher, has a beautiful name for what Bergson describes: sacred indifference. It consists, he says, "in according no preference to any of the beings upon our path, in giving everyone our entire presence, and responding with precise faithfulness to the call they utter to us." 67 Sacred indifference is what human rights strive for. This is the case for human rights considered as a moral and political project: the absolute and incommensurable justice it represents depends on an impartiality that closed morality denies itself. This is also the case for human rights considered as an existential option, with its joyous release from partiality and hatred. To thus care for others (for all others) without prejudice, and to thus also care for oneself by attaining love, joy, and generosity, it is necessary to leap away from direct attachment to other people. Human rights, astonishingly, are a springboard to do just that. ${ }^{6}$ 
1 I have the following works in mind: Suzanne Guerlac, Thinking in Time: An Introduction to Henri Bergson (Ithaca: Cornell University Press, 2006), Leonard Lawlor, The Challenge of Bergsonism: Phenomenology, Ontology, Ethics (London: Continuum, 2003), Keith Ansell-Pearson, Philosophy and the Adventure of the Virtual: Bergson and the Time of Life (London: Routledge, 2002), John Mullarkey, Bergson and Philosophy (Edinburgh: Edinburgh University Press, 1999), Michael Foley, Life Lessons from Bergson (London: Macmillan, 2013), Elizabeth Grosz, Becoming Undone: Darwinian Reflections on Life, Politics, and Art (Durham: Duke University Press, 2011), Elizabeth Grosz, The Nick of Time: Politics, Evolution, and the Untimely (Durham: Duke University Press, 2004), Mark Antliff, Inventing Bergson: Cultural Politics and the Parisian Avant-Garde (Princeton: Princeton University Press, 1992), William Barnard, Living Consciousness: The Metaphysical Vision of Henri Bergson (Albany: SUNY, 2011), Heath Massey, The Origin of Time: Heidegger and Bergson (Albany: SUNY, 2015), Alexandre Lefebvre and Melanie White, Bergson, Politics, and Religion (Durham: Duke University Press, 2012), Michael Kelly, Bergson and Phenomenology (London: Palgrave Macmillan, 2010), Charlotte de Mille and John Mullarkey, Bergson and the Art of Immanence: Painting, Photography, Film (Edinburgh: Edinburgh University Press, 2015), and S. E. Gontarski, Paul Ardoin, and Laci Mattison, Understanding Bergson, Understanding Modernism (London: Bloomsbury, 2014).

2 See Mark Antliff, Avant-Garde Fascism: The Mobilization of Myth, Art, and Culture in France, 1909-1939 (Durham: Duke University Press, 2007), Lefebvre and White (eds.), Bergson, Politics, and Religion, and Donna V. Jones, The Racial Discourses of Life Philosophy: Négritude, Vitalism, and Modernity (New York: Columbia University Press, 2010).

${ }^{3}$ Alexandre Lefebvre, Human Rights as a Way of Life: on Bergson's Political Philosophy (Stanford: Stanford University Press, 2013).

${ }^{4}$ Philippe Soulez and Frédéric Worms, Bergson (Paris: PUF, 2002), 160.

${ }^{5}$ Ibid, 185.

${ }^{6}$ Henri Bergson, Mélanges (Paris: PUF, 1972), 1351. See also ibid., 1420-21. In a later work, Bergson deepens the idea that intellectual cooperation can work for greater global peace: "Anyone who is thoroughly familiar with the language and literature of a people cannot be wholly its enemy. This should be borne in mind when we ask education to pave the way for international understanding." Henri Bergson, The Two Sources of Morality and Religion, trans. R. Ashley Audra and Cloudesley Brereton (Notre Dame: University of Notre Dame, 1977), 286.

${ }^{7}$ Mary Ann Glendon, The Forum and the Tower: How Scholars and Politicians Have Imagined the World, from Plato to Eleanor Roosevelt (Oxford: Oxford University Press, 2011), 3-6.

8 Soulez and Worms, Bergson, 263-65. Soulez and Worms caution that these facts are perhaps apocryphal. Although widely reported at the time by friends and commentators, there is no documentary evidence from Bergson himself to serve as confirmation.

9 Moyn's thesis has inspired other works in the history of human rights, including Stefan-Ludwig Hoffman, Human Rights in the Twentieth Century (Cambridge: Cambridge University Press, 2010) and Jan Eckel and Samuel Moyn, The Breakthrough: Human Rights in the 1970s (Philadelphia: Pennsylvania University Press, 2013).

10 Samuel Moyn, The Last Utopia: Human Rights in History (Cambridge: Harvard University Press, 2010), 8. 
11 For a sample of such a debate, see Susan Marks, "Four Human Rights Myths," in Human Rights: Old Problems, New Possibilities, eds. David Kinley, Wojciech Sadurski, and Kevin Walton (London: Routledge, 2013) and Moyn's reply in Samuel Moyn, "A Powerless Companion: Human Rights in the Age of Neoliberalism," Law and Contemporary Problems 77.4 (2014): 147-69.

${ }^{12}$ Moyn, The Last Utopia, 5.

${ }^{13}$ Lynn Hunt, Inventing Human Rights: A History (New York: Norton, 2008), 27.

${ }^{14}$ Ibid, 35-69.

15 Ibid, 146-75. Hunt first develops this argument in the Introduction to her edited documentary history. See Lynn Hunt, The French Revolution and Human Rights: A Brief Documentary History (New York: St Martin's Press, 1996).

16 Hunt, Inventing Human Rights, 150.

17 Ibid, 147.

$18 \mathrm{Ibid}, 146$.

${ }^{19}$ Moyn, The Last Utopia, 6, 8. "Church history" is Moyn's term to describe a type of historiography which treats its cause or guiding idea as "discovered rather than made in history" (6).

20 Bergson, The Two Sources, 101.

${ }^{21}$ Ibid, 33

22 Ibid, 30.

${ }^{23}$ Frans de Waal, "Morally Evolved: Primate Social Instincts, Human Morality, and the Rise and Fall of 'Veneer Theory,"' in Primates and Philosophers, eds. Josiah Ober and Stephen Macedo (Princeton: Princeton University Press, 2006), 55. I note de Waal makes no reference to Bergson.

${ }^{24} \mathrm{Ibid}, 53$.

${ }^{25}$ Frans de Waal, "The Tower of Morality," in Primates and Philosophers: How Morality Evolved, eds. Stephen Macedo and Josiah Ober (Princeton: Princeton University Press, 2006), 163-64. Another contemporary author close in spirit to Bergson and to de Waal is Joshua Greene. See Joshua Greene, Moral Tribes: Emotion, Reason, and the Gap Between Us and Them (New York: Penguin, 2014). In Moral Tribes he argues from a combination of utilitarianism and evolutionary theory that morality and love are biological mechanisms enabling cooperation and reproduction and, more pointedly, that the evolved morality which helps members of a community to cooperate is not conducive to a similar harmony between members of different communities. As he puts it, "Insofar as morality is a biological adaptation, it evolved not only as a device for putting Us ahead of Me, but as a device for putting Us ahead of Them" (24).

26 Bergson, The Two Sources, 31.

27 Ibid, 287.

28 Jacques Chevalier, Entretiens avec Bergson (Paris: Plon, 1959), 215.

29 Lefebvre, Human Rights as a Way of Life, 3-31.

${ }^{30}$ Bergson, The Two Sources, 9-30.

${ }^{31}$ Ibid, 37. 
32 lbid, 38.

33 Vladimir Jankélévitch, Henri Bergson, trans. Nils Schott (Durham: Duke University Press, 2015), 158.

34 Jankélévitch, Henri Bergson, 153, translation modified. See also Vladimir Jankélévitch, The Bad Conscience, trans. Andrew Kelley (Chicago: University of Chicago Press, 2015), 7-8.

35 Bergson, The Two Sources, 47-48, 74- 238. See Nadia Yala Kisukidi, Bergson ou l'humanité créatrice (Paris: Crns., 2013).

${ }^{36}$ Bergson, The Two Sources, 34.

37 Ibid, 59-60, translation modified.

38 Ibid, 282.

${ }^{39}$ Bergson, Mélanges, 1566.

${ }^{40}$ Bergson, The Two Sources, 59, translation modified.

41 Ibid, 96, translation modified.

42 Ibid, 35, 100, 214.

43 Jankélévitch, Henri Bergson, 155.

${ }^{44}$ Bergson, The Two Sources, 38, translation modified.

45 Ibid, 33.

46 Ibid, 311.

47 Ibid, 38, 54, 232, 230. See Lefebvre, Human Rights as a Way of Life, 92-100, and Alexandre Lefebvre, “Jankélévitch on Bergson: Living in Time," in Vladimir Jankélévitch Henri Bergson (Durham: Duke University Press., 2015).

48 Plato, Symposium, 210a-212c in Plato, Complete Works, eds. John M Cooper and D. S. Hutchinson (Indianapolis: Hackett, 1997). See Jacob Taubes, The Political Theology of Paul, trans. Dana Hollander (Stanford: Stanford University Press, 2004), 55.

${ }^{49}$ Bergson, The Two Sources, 38.

50 lbid, 73.

51 See Melanie White, "Habit as a Force of Life in Durkheim and Bergson," Body and Society 19.2-3 (2013): 240-62.

52 Bergson, The Two Sources, 15.

${ }^{53}$ Extended discussion of joy can be found in both Bergson's very earliest and very last works. Joy features in his very early Extracts from Lucretius (1884), which is not surprising given that it is a commentary on Epicureanism. It is also the first emotion he examines in terms of duration in Time and Free Will (1889). His most important discussions of joy are to be found in Two Sources and Creative Mind (1934). See Alexandre Lefebvre, "Bergson, Human Rights, and Joy," Continental Philosophy Review 49.4 (2016): 1-25.

${ }^{54}$ Henri Bergson, Mind-Energy, trans. H. Wildon Carr (London: Palgrave Macmillan, 2007), 23. 
${ }^{55}$ Henri Bergson, The Creative Mind (New York: Citadel Press, 2002), 86. I note that three essays in Creative Mind ("The Possible and the Real," "Philosophical Intuition," and "The Life and work of Ravaisson") conclude with a discussion of joy, and the privileged relation between joy, creation, and philosophy.

${ }^{56}$ Bergson, The Two Sources, 58.

57 Ibid.

${ }^{58}$ On the wider tradition, largely Christian but also extending into Romanticism, on the connection between joy and self-overcoming, see Adam Potkay, The Story of Joy: from the Bible to Late Romanticism (Cambridge: Cambridge University Press, 2007), 30-49.

${ }^{59}$ See my Human Rights as a Way of Life, 3-5, 15-31.

${ }^{60}$ Hunt, Inventing Human Rights, 147.

${ }^{61}$ Bergson, The Two Sources, 264.

62 See my Human Rights as a Way of Life, 100-109.

${ }^{63}$ See Charles Taylor, A Secular Age (Cambridge: Harvard University Press, 2007), 282.

${ }^{64}$ Bergson, The Two Sources, 54.

${ }^{65} \mathrm{Ibid}, 235$.

${ }^{66} \mathrm{Ibid}, 39$.

${ }^{67}$ Louis Lavelle, The Dilemma of Narcissus, trans. W. T. Gairdner (London: George Allen \& Unwin, 1973), 99.

${ }^{68}$ I thank Melanie White and Mark William Westmoreland for all their help with this article. 